\title{
Anthropometry Description In Households That Experiences Obesity
}

\author{
Muriyati 1, Ilhamsyah ${ }^{2}$, Suhartini Nur ${ }^{3}$ \\ Departemen Medical Surgical Nursing, Stikes Panrita Husada Bulukumba ,Indonesia ${ }^{1}$ \\ Departemen Medical Surgical Nursing , Universitas Islam Negeri Alauddin Makassar, Indonesia ${ }^{2}$ \\ S1 Nursing Study Program, Stikes Panrita Husada Bulukumba, Indonesia ${ }^{3}$
}

Corresponding Autor : muriyati.stikes@gmail.com

\begin{abstract}
ABSTRAK
Obesity is defined as abnormal or excessive fat accumulation that can interfere with health. In 2015, more than 1.9 billion adults were overweight and 400 million of them were obese. Various types of anthropometry can be used to determine the occurrence of obesity, these methods include measurement of body mass index (BMI). Arm circumference, and abdominal circumference. Body mass index is an indicator of obesity that is widely used to estimate the composition of body fat. Based on an initial survey conducted in April-May the number of obesity increased until June-July 2018. From the results of a preliminary study conducted by researchers, more productive-age housewives were obese I than obesity II. An anthropometric picture of obese housewives in Taccorong Village, Bulukumba District was known. The method used in this research is descriptive with a simple approach. Sampling was carried out with a purposive sampling technique. The population in this study was 1,011 people. The sample in this study was 62 respondents. The results of this study indicate that housewives of productive age who have a picture (obesity I) BMI 25-29.9 amounted to 59.7\%, and (obesity II) BMI $\geq 30$ by $40.3 \%$, normal upper arm circumference of $24,2 \%$, abnormal upper arm circumference $75.8 \%$, and abdominal circumference $62 \%$. The conclusion of this study is that housewives who are obese in Taccorong Village, Bulukumba Regency are based on productive age (15-49) years old, with young adults (18-35) years totaling 37 (59.7\%) respondents and old adulthood (36-49 ) year totaling 25 (40.3\%) respondents. It is recommended for housewives to improve a healthy lifestyle to avoid obesity which can lead to degenerative diseases.
\end{abstract}

Keywords: Anthropometry, Obesity

\section{INTRODUCTION}

According to the Indonesian dictionary, a housewife is interpreted as a woman who has an important role and regulates various kinds of administration in the household. For housewives who lack physical activity greatly affect their health, supplemented with more food intake. This causes the accumulation of fat which will result in overweihght and obesity (Novitasary, et al, 2013). Impact caused by excess body weight (overweight) that can continue to obesity and increase the risk of disease in the body. Like, coronary heart disease, hypertension and diabetes mellitus. Where productive age are women who are of childbearing age (WUS) aged 15-49 years and women at this age still have the potential to have offspring. So it is likely to have an impact on children. 
While overweight and obesity in women of childbearing age (15-49) have an impact on the female reproductive cycle, which causes infertility in women due to anovulation, irregular menstrual cycles, increasing the risk of miscarriage, and even fetal death. Therefore it is important to maintain body mass index in women of childbearing age within normal limits because women of childbearing age are in the preconception period, which is a critical period affecting children or offspring at birth and in later life (Kirana, et al. 2017).

WHO (Word Health Organization) in 2015 at this time 1.6 billion adults around the world are overweight, and at least 400 million of them are obese. While in 2016 overweight and obesity kill more people than with people who are malnourished. More than 1.9 billion people aged 18 years and over are overweight (MOH, 2015). The results of Riskesdas (2013) show that the prevalence of overweight or overweight in Indonesia reaches $13.5 \%$ and obesity is $15.4 \%$. The prevalence of overweight and obesity in 2016 is the highest prevalence in Jakarta and Bali around 3,3\% then the Riau Archipelago $3.0 \%$ and the lowest is Papua 2.7\%. The prevalence of obesity by sex in the District / City in (2014), Makassar City as many as 344 people. There were 114 men and women as many as 230 people (Makassar City Health Profile, 2014). Based on data from Bulukumba District in 2016, the prevalence of obesity is 913 people or $49.3 \% .115$ men (7.21\%) people, 798 women (50.03\%) people collected from several puskesmas. The highest prevalence is in the working area of the Bonto Bahari Puskesmas as many as 425 people (44.6\%) and the lowest in the Caile Puskesmas working area is 38 people (36.54\%). There are 13 puskesmas that do not record overweight and obesity, one of which is Puskesmas Bontonyeleng (Health Office of Bulukumba City, 2016).

Data obtained from the Taccorong Village office in 2018 found that there were 1,011 housewives (52.82\%). Based on the initial survey conducted by researchers on housewives as many as 87 people in the Village of Taccorong (2018). Found housewives who are included in the category of obesity with childbearing age (15-49) years as many as 64 people who later overweight as many as 16 people. The facts show that it is true that there are housewives who are overweight and obese in Taccorong Village, which will certainly have an impact on their daily health and activities. Housewives are more at risk of overweihgt and obesity because they have entered productive age. Therefore, it is necessary to examine overweight and obesity to detect the overall amount of obesity to prevent various health problems resulting from overweight and 
obesity. So that researchers are interested in conducting research about "Anthropometric description of housewives in Taccorong Village".

\section{MATERIAL AND METHODS}

This study uses a descriptive research design with a simple approach (Dharma, 2015), which aims to get a picture of body mass index in obese housewives in Taccorong Village. The population is the whole object of the study or the object under study (Notoatmodjo, 2012). The population in this study were all housewives in Taccorong Village, Bulukumbab Regency with a total of 1,011 people. Samples are objects that are studied and are considered to represent the entire study population (Notoatmodjo, 2012). The sample in this study were obese housewives who met the inclusion criteria in Taccorong Village. The instrument used in this study was observation. Observation is a data collection technique using a stature meter and digital weight scales to determine body mass index in housewives.Data were analyzed based on measuring scale and research objectives using computerized program software. Data were analyzed by: (1). Univariate analysis is what is done analyzing each variable from the results of Notoatmodjo's research (2012). Univariate analysis functions to summarize the data set of measurement results in such a way. In this analysis in the form of tables and graphs. In this study, we will know the frequency distribution of antripometric characteristics in obese housewives. (2). Bivariate Analysis is an analysis conducted by more than two variables. Bivariate analysis serves to determine the relationship between variables Notoatmodjo, (2012).

RESULTS

Table 1. Distribution of Age and Education Characteristics

\begin{tabular}{ccc}
\hline Age & Frequency & Percentage (\%) \\
\hline Young Adult & 37 & 59.7 \\
Older adults & 25 & 40.3 \\
\hline Level Of Education & & 74.2 \\
Basic & 46 & 24.2 \\
Middle & 15 & 1.6 \\
Bachelor & 1 & $\mathbf{1 0 0 . 0}$
\end{tabular}

Based on table 1, the frequency distribution of productive age is 62 respondents with the number of young adults 37 respondents or around (59.7\%), old adulthood is 25 respondents or around (40.3\%). Meanwhile, the distribution based on basic education criteria was 46 respondents or around (74.2\%), secondary education criteria 
were 15 respondents or around (24.2\%), and higher education criteria were 1 respondent or around (1.6\%).

Table 2. Frequency Distribution Of Upper Arm Circumference Of Housewives

\begin{tabular}{ccc}
\hline Arm Circumference & Frequency & Percentage (\%) \\
\hline Normal & 15 & 24.2 \\
Abnormal & 47 & 75.8 \\
\hline Amount & 62 & 100.0 \\
\hline
\end{tabular}

Based on (table 2), the frequency distribution of abnormal arm circumference criteria was 47 respondents (75.8\%), normal arm circumference was 15 respondents $(24.2 \%)$.

Table 3. Distribution of Frequency of Abdominal Circumference of Housewives

\begin{tabular}{ccc}
\hline Stomach Circumference & Frequency & Percentage (\%) \\
\hline Stomach Circumference normal & 0 & 0 \\
Stomach Circumference Abnormal & 62 & 100.0 \\
\hline Amount & 62 & 100.0 \\
\hline
\end{tabular}

Based on (table 3), the frequency distribution of abnormal abdominal circumference criteria was 62 respondents (100.0\%).

Table 4. Distribution of Obesity Frequency Based on Obesity I and ObesityII

\begin{tabular}{ccc}
\hline Obesitas & Frequency & Percentage (\%) \\
\hline Obesity 1 (IMT 25-29,9) & 37 & 59,7 \\
Obesity 2 (IMT > 30) & 25 & 40,3 \\
\hline Amount & 62 & $\mathbf{1 0 0 . 0}$
\end{tabular}

Based on (table 4), the distribution of obesity frequency based on obesity I and obesity II in Taccorong Village is obesity criteria I as many as 37 respondents or around (59.7\%), while obesity criteria II is 25 respondents or around (40.3\%).

\section{DISCUSSION}

Based on the results of research conducted in the Village of Taccorong. It can be seen that of the 62 respondents who were obese, based on obesity I were 37 respondents or around (59.7\%), while obesity II were 25 respondents or around (40.3\%). Researchers argue that the incidence of obesity in the village of Taccorong is quite high, where housewives who are obese are caused by unhealthy eating patterns. The habit of consuming oily and fatty foods such as fried foods, chin and supported with less physical activity, no other activities other than homework. Triggering an increase in the value of body mass index (BMI). This is because oily foods such as fried foods 
contain a lot of oils which are high in calories. When calories as a source of energy are more than needed, the body will store excess as fat so that the accumulation of fat in the body causes excess weight. In line with research conducted by Nugroho, et al, (2016) that there is a relationship between physical activity and changes in body mass index.

Viewed from the characteristics of education more obese people in primary education than secondary education and higher education. The lower the level of education, the less information obtained so that it tends to make a less healthy lifestyle. Lack of housewife activity and unhealthy lifestyles so that it can have an impact on degenerative diseases such as hypertension and diabetes mellitus. This happens because of the lack of public awareness of the impact of food and drinks consumed every day, so people need to be aware of a healthy lifestyle to avoid obesity. This is in line with research conducted by Prasetyorini (2010) that there is a relationship between the level of knowledge about the method of weight loss.

Based on the results of research conducted in the Village of Taccorong. It can be seen that from 62 respondents with normal arm circumference of 14 respondents (22.6\%), while arm circumference is not normal as many as 48 respondents (77.4\%). Researchers believe there is still a respondent's arm circumference that exceeds the normal limit due to lack of activity and uncontrolled eating patterns, more activities of sitting, sleeping, and watching TV and consuming foods that are oily, bersantan, and consume less fruit. The lifestyle of a housewife is influential because it is related to physical activity. The more modern the life of a housewife, the less physical activity is carried out. This is caused by the times that tend to provide convenience so that activity is reduced and causes fat mass to increase because energy from food is stored as reserve fat. The formation of fat contributes to an increase in the size of the upper arm circumference. In line with research conducted by Ariyani, et al (2012) that the results of correlation analysis show that upper arm circumference is closely related to body mass index.

Based on the results of research conducted in Taccorong Village the number of respondents based on abdominal circumference of housewives with abdominal circumference $\geq 80 \mathrm{~cm}$ was 62 respondents (100.0\%). Researchers believe that the overall abdominal circumference of respondents experiencing abnormal abdominal circumference, this happens because of a lack of knowledge about obesity so it does not regulate healthy lifestyles, and exercise only doing homework activities. Based on the 
theory that supports from Wirakusuma (2010) that regular exercise will help you lose weight. This is in line with research Finrisk studies (2012) found that people with mild activity have a greater chance of being obese. Examples of people with mild activities are those who spend more leisure time watching TV and also those who prefer to use vehicles such as motorcycles rather than on foot. The greater the circumference of a person's stomach, the more easily he is attacked by degenerative diseases such as coronary heart disease, and diabetes mellitus. This is because fat in the abdomen is an active fat cell that can disrupt blood cholesterol levels, so bad cholesterol levels in the blood also increase and cause accumulation of fat in blood vessels (Nyoman, 2002). In line with research conducted by Wahyu \& Hidayati, (2014) that abdominal circumference has a significant correlation with the incidence of obesity which can cause coronary heart disorders.

\section{CONCLUSIONS}

Based on the results of the study above, it was concluded that body mass index in Taccorong Village, Bulukumba Regency in 2018, namely obesity I was more than obesity II. Abdominal circumference in housewives in Taccorong Village with abdominal circumference $\geq 80 \mathrm{~cm}$ is categorized as obese all respondents have an abnormal abdominal circumference. Arm circumference in housewives in Taccorong Village with more abnormal arm circumference compared to normal arm circumference. Researchers suggest that the results of this study can be used as material to increase insight in the field of research and increase knowledge about anthropometry in housewives with obesity in Taccorong Village, Bulukumba Regency in 2018. As a reference for basic data for the Bontonyeleng Community Health Center so as to form a cadet that can record obesity and detect obesity thorough. It is recommended that women of childbearing age begin to adopt a healthy lifestyle that is maintaining a healthy diet and exercising regularly so as to prevent excess weight gain. By knowing the results of this study, it is expected to be a reference or consideration for students, especially nursing to pay more attention to a healthy lifestyle to reduce the incidence of obesity.

\section{REFERENCES}

Ango, K. A., \& Ottay, G. A. (2016). Sikap Guru Mengenai Intervensi Aktifitas Fisik dan Diet Pada Siswa Obesitas di Sekolah Dasar. Jurnal Kedokteran Komunitas dan Tropik Volume 4, Nomor 2 Mei 2016. 
Astuti, L. D. (2015, Agustus Jumat). Retrieved April Rabu, 2018, from Mayoritas Ibu Rumah Tangga Menggemuk: https://www.google.com

Baladraf, F., E. Surachmanto, E., \& Sy. Moeis, E. (2013). Hubungan Indeks Massa Tubuh Dengan Laju Filtrasi Glomerolus Pada Mahasiswa Dengan Obesitas di Fakultas Kedokteran Universitas Sam Ratulangi. Jurnal e-Biomedik (eBM) Volume 1, Nomor 1, Maret 2013.

Bidjuni, H., Rompas, S., \& Bambuena, M. I. (2014). Hubungan Pola Makan Dengan Kejadian Obesitas Pada Anak Usia 8-10 Tahun Di SD Katolik 03 Frater Don Bosco Manado. Jurnal Keperawatan Vol 2, No 2 (2014) E-Jurnal Keperawatan .

Budiyati, Wanda, D., \& Hartoyo, M. (2013). Hubungan Indeks Massa Tubuh Ayah dan Ibu dengan Kejadian Obesitas Pada Anak Usia Sekolah Di SD Islam Al-Azhar 14 Kota Semarang . Prosiding Konferensi Nasional PPNI Jawa Tengah 2013.

Dahlan, S. (2016). Besar Sampel Dalam Penelitian Kedokteran dan Kesehatan. Jakarta: Epidemologi Indonesia .

Damasanti, R. (2012). Hubungan Indeks Massa Tubuh dengan Aktivitas Fisik Wanita di Perumahan Gendongan Kolomadu.

Danari, A. L., Muyulu, N., \& bala, F. O. (2013). Hubungan Aktivitas Fisik Dengan Kejadian Overwight dan Obesitas Pada Anak SD di Kota Manado. ejurnal Keperawatan (eKp) Volume 1, Nomor 1, Agustus 2013.

Depkes RI Jakarta . (2012). Departemen Kesehatan Indonesia, Profil Kesehatan Indonesia.

Dharma, K. K. (2015). Metodologi Penelitian Keperawatan. Jakarta: CV. Trans Info Media.

DietSehat.co.id. (2018). Informasi Diet Sehat Indonesia. program Diet Untuk Obesitas .

Erika, K. A., \& Nurachmah, E. (2014). pengaruh pendekatan Child Helthcare Model dan Transtheoretical Model Terhadap Asupan makan Overweight dan obesitas . Jurnal kesehatan Masyarakat Nasional.

Faridi, A., \& Hidayati, W. (2016). Analisis Faktor Risiko Kejadian Obesitas Sentral Pada Ibu Rumah Tangga di Perumahan Griya Labuan Asri Desa Sukamaju Kecamatan Labuan Kabupaten Pandeglang Banten Tahun 2016. Prosiding Kolokium Doktor dan Seminar Hasil Penelitian Hibah .

Hellosehat.com. (2018, februari). Bamandhita Rahma Setiaji. Retrieved april minggu, 2018, from Tips sehat hidup sehat.

http: //www.who.int/mediacentre/factsheets/fs311/en/. (2016). Retrieved Maret Kamis, 2018

Isnaini, Sartono, A., \& Winaryati, E. (2012). Hubungan Pengetahuan Obesitas dengan Rasio Lingkar Perut Pada Ibu rumah Tangga di Desa Pepe Krajan Kecamatan TegowanuKabupaten Grobongan . jurnal Gizi Universitas Muhammadiyah Semarang November 2012 Volume 1 Nomor 1. 
K. Moha, M., Bidjuni, H., \& Lolong, J. (2017). Hubungan Obesitas Dengan Harga Diri Pada Remaja di SMA Negeri 1 Limboto Kecamatan Limboto Kabupaten Gorontalo. $e$ journal Keperawatan (e-Kp).

Keperawatan medikal bedah . (2014). Singapore: Salemba Medika .

Kumesan, O., Ticoalu, S., \& Pasiak, T. (2016). Hubungan Lingkar Lengan Atas dengan Obesitas Pada Mahasiswa Fakultas Kedokteran Universitas Sam Ratulangi. Jurnal e-Biomedik (eBm), Volume 4, Nomor 2, Juli-Desember 2016.

Kurniawati, Y., Fakhriadi, R., \& Yulidasari, F. (2016). Hubungan Antara Pola Makan, Asupan Energi, Aktifitas Fisik, Dan Durasi Tidur Dengan Kejadian Obesitas Pada Polisi. Jurnal Publikasi Kesehatan Masyarakat Indonesia, Vol.3 No.3, Desembaer 2016.

Kussoy, K., Fatimawali, \& Kepel, B. (2013). Prevalensi Obesitas Pada Remaja Di Kabupaten Minahasa. Jurnal e-Biomedik Volume 1, Nomor 2, Juli 2013.

Lasabuda, T., M. Wowor, P., \& Mewo, Y. (2015). Gambaran Indeks Massa Tubuh (IMT) Jamaah Mesjid Al- Fatah Malalayang . Jurnal e-Biomedik (eBm) Volume 3, Nomor 3, September-Desember 2015.

Liwang, f., hanifati, s., tanto, C., \& adip, e. p. (2014). Kapita selekta kedokteran. Jakarta: Media Aesculapius.

M.Black, J., \& Hawks, J. H. (2014). Keperawatan Medikal Bedah. Singapura: Elsevier.

Muriyati, \& Syamsuddin. (2017). Dasar - Dasar Overweight Obesitas Aerobik. Jawa Timur Indonesia: Wade Group.

Negara, K. N., Wibawa, A., \& S. P. (2014). Hubungan Antara Indeks Massa Tubuh (IMT) Kategori Overweight Dan Obesitas Dengan Keluhan Low Back Pain pada mahasiswa fakultas kedokteran .

Notoatmodjo, S. (2012). Metodologi penelitian kesehatan. Jakarta: Rineka cipta.

Novitasary, M. D., Mayulu, N., \& Kawengian, S. E. (2013). Hubungan Antara Aktivitas Fisik dengan Obesitas pada Wanita Usia Subur . Jurnal e-Biomedik (eBM), Volume 1, Nomor 2, Juli 2013.

Nugroho, K., Mulyadi, \& Masi, G. N. (2016). Hubungan Aktivitas Fisik Dengan Perubahan Indeks Massa Tubuh Pada Mahasiwa semester 2 Program Studi Ilmu Keperawatan Fakultas Kedokteran . e-Jurnal Keperawatan (e-Kp) Volume 4 Nomor 2, Juli 2016.

Prasetyorini, H. T., \& Febrijanto, y. (2010). Studi tingkat pengetahuan tentang metode penurunan berat badan pada mahasiswa overweight di stikes RS Baptis Kediri. jurnal stikes RS. Baptis Kediri Volume 3, Nomor 2, Desember, 2010.

Proverawati, A. (2010). Obesitas dan Gangguan Prilaku Makan Pada Remaja. Yogyakarta: Nuha medika. 
Putra, P. E. (2016). Gambaran Tingkat Depresi dan Obesitas Pada Mahasiswa Fakultas Kedokteran Angkatan 2013 . E-Jurnal Medika, VOL.5 NO.5, MEI, 2016.

Putra, W. N. (2017). Hubungan Pola Makan, Aktivitas fisik dan aktivitas sedentari dengan overweight di SMA negeri 5 surabaya. Jurnal Berkala Epidemiologi .

Putri, N. M., Wibawa, A., Sugiritama, I. W., \& Muliarta, I. M. (2016). Wanita Overweight Dan Obesitas Memiliki Sudut Eversi Calcaneus Lebih Besar Dan Ekstensibilitas Gastrocnemius Lebih Kecil Dari Pada Wanita Normal. Majalah IImiah Fisioterapi Indonesia (MIFI) Vol 1, No 1 (2016).

Ratningrum, G., \& Dieny, F. F. (2015). Kualitas Diet dan Aktivitas Fisik Pada Remaja Obesitas dan Non Obesitas. Journal of nutrition college, Volume 4, nomor 2, Tahun 2015.

Rininta, N. M., Wibawa, A., Sugiritma, W., \& Muliarta, M. (2016). Wanita overweight dan obesitas memiliki sudut eversi calcaneus lebih besar dan ekstensibilitas gastrocnemius lebih kecil daripada wanita normal didesa mengesta, kecamatan penebel,kabupaten tabanan. majalah ilmiah fisioterapi Indonesia .

Ruslie, R. H., \& Harmadi. (2012). Analisis Regresi Logistik Untuk Faktor-Faktor Yang Mempengaruhi Status Gizi Remaja. Majalah Kedokteran Andalas No.1, Vol.36. Januari-Juni 2012.

Sari, V. P. (2012). Perbedaan Prestasi Belajar Antara Anak Sekolah Dasar Penderita Obesitas Dan Status Gizi Normal. Jurnal Kesehatan Masyarakat Volume 1, Nomor 2, 2012 .

Setiadi. (2013). Konsep dan Praktik Penulisan Riset Keperawatan (Edisi II). Yogyakarta: Graha Ilmu.

Setiawati, B., Wati, A. S., \& Maisya, I. B. (2017). Usia Dan Indeks Massa Tubuh Merupakan Determinan Tekanan darah Diatas Normal Pada Wanita Usia Subur. Penelitian Gizi dan Makanan .

Soetjiningsih. (2010). Tumbuh Kembang Remaja Dan Permasalahannya . Jakarta: Sagung Seto.

Sugiritama, W., Wiyawan, S., Arijana, \& Ratnayanti. (2015). Gambaran IMT (Indeks Massa Tubuh) Kategori Berat Badan Lebih dan Obesitas pada Masyarakat Benjar

Supariasa, I. D., Bakri, B., \& Fajar, I. (2014). Penilaian Status Gizi. Jakarta: EGC.

Susanto. (2010). Cegah dan Tangkal Penyakit Modern (Hipertensi, Stroke, Jantung, Kolestrol, Diabetes ). Yogyakarta: ANDI.

Triwanto, A., Muljati, S., \& Jahari, A. B. (2015). Cut Of Point Indeks Massa Tubuh dal Lingkar Perut sebagai Indikator Rasiko Diabetes dan Hipertensi. Pada Orang Dewasa di Indonesia . 
Watulingas, I., Rampengan, J. J., \& Polii, H. (2013). Pengaruh Latihan Fisik Aerobik Terhadap V02 Max pada Mahasiswa Pria dengan berat badan berlebih (overweight) . jurnal e-Biomedik.

WHO, \& Pasifik, A. (2018, Maret Selasa). Perawatan Kesehatan.com. Retrieved from Uncategorized.

www.ijhn.ub.ac.id. (2017, juni kamis). Karina, $d k k$. Retrieved april sabtu, 2018, from IMT wanita usia subur .

Zilvano, H., Darmono, \& Angriani, M. T. (2013). Hubungan Tingkat Konsumsi Dan Aktivitas Fisik Dengan IMT (Index Massa Tubuh). Jurnal Kedokteran Muhammadiyah Volume 1, Nomor 2 Tahun 2013. 